\title{
Erratum to: Political and institutional environment and privatization prices
}

\author{
Alberto Chong · Jorge Guillen · Alejandro Riano
}

Published online: 1 April 2011

(C) Springer Science+Business Media, LLC 2011

Erratum to: Public Choice (2010) 142: 91-110

DOI 10.1007/s11127-009-9476-1

This article is an adaptation of Chong, A. \& Riano, A. Political environment and privatization prices. Inter-American Development Bank working paper \#549, 2006.

The online version of the original article can be found under doi:10.1007/s11127-009-9476-1.

A. Chong $(\bowtie)$

Research Department, Inter-American Development Bank, Washington, DC, USA

e-mail: albertoch@iadb.org

J. Guillen

CENTRUM, Universidad Catolica, Lima, Peru

A. Riano

Department of Economics, Pennsylvania State University, College Park, PA, USA 